\title{
KAMUSAL ALANIN OLUŞUMU, DÖNÜŞÜMÜ VE İKTISSADİ BOYUT
}

\author{
Nihat FALAY*
}

$\ddot{O ̈ z e t}$

Kamusal alan kavramı günümüzde ciddi tartısmaların kaynağıdır. Kamusal alanın tanımlanması ve kapsamının belirlenmesi sosyal bilimciler açısından önemli bir gündem oluşturmaktadır. Özellikle kamusal alanın iktisadi boyutunun belirlenmesinde iktisadi ve mali süreçlerin işleyişi büyük önem taşır. Bu çalışmada, kamusal alanın oluşumu ve dönüşümü tarihsel süreçte ele alınmıştır. Tarihsel gelişimden hareketle, kamusal alanın iktisadi boyutunu oluşturan iktisadi ve mali süreçler analiz edilmiştir.

Anahtar Kelimeler: Kamusal Alan, Demokrasi, Ekonomi

JEL Kodu: H49, P59, Z13

\section{THE FORMATION AND TRANSFORMATION OF PUBLIC SPACE AND ECONOMIC DIMENSION}

\begin{abstract}
Public space term is the source of significant debates recently. Defining the public space and determining the scope of it becomes important agenda for social scientist. The running of economical and fiscal processes is especially important in the determination of economical dimension of public space. In this study, the formation and transformation of public space is dealed with historical processes. Based on historical development, economical and fiscal processes which form economical dimension of public space are analyzed.
\end{abstract}

Keywords: Public Space, Democracy, Economy

JEL Codes: H49, P59, Z13

Prof. Dr., İstanbul Üniversitesi (Emekli), E-mail: nfalay@istanbul.edu.tr 


\section{GİRIŞ: KAMUSAL ALAN}

Antik çağda Roma kamu (publicus) sıfatı, yurttaşları ya da tebaayı (res publica) anlatmak için kullanılırdı. Bunun yanında, Romalılar kamu ile bireysel ev alanı arasında da bir ayırıma gider ve bu mantıkla, sokak, meydan, tiyatro gibi kamusal alanları kamu olarak nitelendirirler idi. İsim olarak publicum kelimesi siyasal bir anlam taşıyor ve devletin gelirlerini, topraklarını ve mülkünü ifade ediyordu. Kamunun bu şekilde devlet ile ilişkilendirilmesi modern Avrupa'nın ilk dönemlerinde de yeniden güncellik kazandı. Bu durum bugün de devam etmekte olup bu bağlamda kamu binaları, devlet daireleri ve devlet parklarından bahsedilmektedir.

Kamu (public) sözcüğü, “izlerçevre/dinlerçevre” gibi bir şeyin kitlesi anlamında da kullanılmaktadır. Günümüzde, örneğin, okur kitlesi, sanatsever kitlesi olarak da karşımıza çıkmaktadır. Oysa kamu sözcüğünün dinleyici, izleyici kitlesi anlamında kullanılması ta 17. yüzyılda ortaya çıkmış ve 18.yüzyılda bu sözcük farklı dillere yerleşmiştir. Hemen anlaşılıyor ki bu sözcüğün kullanılmasının devlet otoritesinin uygulanmasıyla doğrudan bir bağlantısı yoktur, çünkü okuyanların, izleyenlerin, ilgili şeyler hakkında yargıda bulunan özel bireylerin oluşturdukları kitleler kastedilmektedir. Kafeler ve salonlar, işte bu kitlelerin görüş ve kanaat bildirmesini sağlayan sosyalleşme alanlarıdır. Bu alanlara gelip, parasıyla söz konusu kültür ürünlerine sahip olabilen kitleler bunun uzantısı olarak bir tüketim kültürü bağlamında kamu olarak ortaya çıkmıştır (Melton, 2011: 11-12).

Habermas'ın 1962'de yazdığı ve Türkçeye “Kamusallığın Yapısal Dönüşümü (Almanca: Strukturwandel der Öffentlichkeit, İngilizce Çevirisi: The Structural Transformation of Public Sphere olan)" adı altında çevrilen kitaptaki "kamusal alan" kavramını, İngilizce çeviriyi yapan Thomas Burger, "public sphere" mantığıyla ele almıştır. Türkçeye de daha çok İngilizce çevirisindeki mantık uzantısında kamusal alandaki mekânsal, fiziksel ve topografik mantık oturmuş gibidir. Oysa Habermas'ın bu kavramdan kastı, mekânsal mantığın ötesinde hem public sphere_hem de kamusal olarak çevrilebilecek public space deyimlerini karşılar durumdadır. Hemen belirtmek gerekir ki kamusal alana mekansal bir anlam eklemek Habermas'ın kastettiği şey değildir (Akşit, 2009: 2).

Sırası gelmişken hemen belirtmek gerekir ki, burada space kavramının alan kavramını çağrıştırmasının yaratacağı anlam kaymalarına ve sphere kavramını tam karşılamayan yorumlara engel olmak için bu kavramı alem, dünya ve küre vb. Türkçemizde mevcut ve daha sıcak karşılıkları kullanmak zihinsel ve semantik çabaları daha kolaylaştırır. Bu bağlamda, ileride kullanılacak olan kavramlar olarak, "ortak alan”, "müşterek alan”, "toplumsal alan" ve hatta "umumi alan" in öne çıkarılması kastedilmektedir. Böylece kavram, "devlet egemenliği, iktidarı" ve mantığı" çağrışımlarından daha kolayca uzaklaştırılmış ve kurtarılmış olacaktır. Dilimize zaten, kати kavramı yanında, uтиm, amme ve menfaat gibi sicak kavramlar geçmişte ve hala yerleşmiş ve bu yönde kullanılıyor durumdadır. Burada tekrar ortaya çıkan husus; bir düşünce veya ifadeyi en iyi şekilde yansıtacak olan yeni veya eski kullanımların bilimsel dile de oturtulması gereğidir.

Kamusal ve kamusal alan kavramlarını yeniden ve derinliğine analiz eden J. Habermas temel bir sorunu gündeme getirmiştir: Kamusal sorunların tartışılmasının mümkün olduğu koşullar nelerdir? Onun, "burjuva kamusal alan" olarak nitelendirdiği kamusal uzamı, sosyalleşme alanları ve biçimleri ile basın kültüründeki beklenmedik gelişmelerin damga 
vurduğu bir iletişim dünyası ile karşı karşıyayız. Burjuva kamusal alanın sözde açıklığının ve görünürde eşitlikçiliğinin, daha baştan "sınıfsal çıkarlarla maskelendiği" ve 19. ve 20. yüzyıllarda tüketim kültürünce soğurulduğunda (emildiği/massedildiğinde) yukarıda belirtilen tartışma ve yorum işlevlerini yitirdiği söylenebilir.

J. Habermas'ın ortaya attığı burjuva kamusal alan kavramı iki temel gelişimin sonucu idi (Melton, 2011: 15-16):

i. Birinci gelişim; 16. yüzyılın sonlarından başlayarak modern ulus devletlerin ortaya çıkışıdır ki; bu çıkışa paralel bir başka süreç, devletten ayrı bir alan olarak toplumun ortaya çıkışıdır. Burada modern devlet, kamu iktidarının alanı; toplum ise kişisel (veya özel) çıkar ve etkinlik alanı olarak ele alınacaktır. Çünkü, Orta Çağda böyle bir ayırım yoktu ve yönetime, askere, adalete ve maliyeye ilişkin işler senyörler, kiliseler, loncalar ve diğer "özel” bireyler ve kurumlar tarafından yerine getiriliyordu. Oysa modern devletler otoritelerini sağlamlaştırdıktan sonra, yukarıda belirtilen işler artık egemen bir devletin eline geçiyordu. Bu otorite veya egemenliğin pekiştirilmesi süreci, 17. ve 18. yüzyılın mutlakiyetçi yönetimlerinde en belirgin hale gelmiştir.

Mutlakiyetçi yönetimlerde kamu otoritesi kralın yönetimi altındaki özel bir tebaanın olmasını gerektirmiştir. Bu durumda devleti egemen gücün mekanı yapmakla toplumu da yaratmış oluyordu. Habermas'ın burjuva kamusal alan dediği modern "sivil toplum"un bir anlamda "embriyo" biçimi bu özel toplumsal dünyada gelişecektir.

ii. Íkinci gelişim; kapitalizmin yükselişinin devlet ve toplum arasındaki bağı koparması, ticari kapitalizmin (merkantalizmin) güçleri aracılığıyla artan bir özerklik kazanmasıdır. Çünkü ulusal ve uluslararası pazarların genişlemesi meta dolaşımını hızlandırmış, dolaşıma giren gazeteler ve ticari kağıtlar yoluyla iletişim ağları yaygınlaşmıştır. Toplumsal ve ekonomik entegrasyon (bütünleşme) toplumun bağımsızlığını güçlendirmiştir. 18. yüzyılda bu yeni bütünleşme ve bağımsızlık hissi düşünce alanında "siyasal iktisat" biliminin doğuşunda açıkça kendini belli etmiştir. 19. yüzyıla gelindiğinde ise, bir yanda devletin siyasal alanı öte yanda bireylerin özel alanlarını birbirinden ayıran "devlet-toplum karşıtlığı" nda en üst noktasına ulaşmıştır (Becker, 1994).

Yaşamın gerçekleşme sürecine eğildiğimizde göreceğimiz şey şudur: Üretim ve mübadelenin başlıca mekanı olarak evin yerini piyasa almış, aile ve ev alanı da buna uygun değişim ve nitelikler göstermiştir. 18. yüzyılda bir mahremiyet (gizlilik) alanı olan yeni burjuva aile anlayışı ortaya çıkmıştır. Oysa ortaçağda soyluların evi hem bir üretim birimi hem de bir tahakküm (baskı/zorbalık) alanı idi. Fakat modern çağın başlarında kapitalizmin ve devletin yükselişi evin daha önceki işlevlerini ortadan kaldırmış ve ürün üretiminin başlıca alanı olarak evin yerini "piyasa" almıştır. Öte yandan daha önce hanehalkının yerine getirdiği işlevleri de giderek devlet üstlenmiştir. Bunun sonucunda "ev" giderek daha özelleşmiş ve hem devlet hem de emek dünyası karşısında fazla özerklik kazanmıştır.

Bunların sonucunda ortaya yeni bir burjuva aile modeli ortaya çıkmıştır ve bu aile modelinde "ev içi alan" bir mahremiyet alanıdır. Yani, bir yandan devletin öte yandan emeğin ve üretimin getirdiği zorunluluklara karşı bir sığınak olarak kabul edilmiştir. 
Evin (yani hane halkının) özerkliği bir evrensel ideal olmakla birlikte, aile bu özerkliğini mülkiyet sahipliği ile sağlıyordu ve bu niteliğine borçluydu. Ama mülkiyet sahibi olmayanların (yani mülksüzlerin) bu aile alanından dişlanması ise burjuva ideolojisinin evrenselliği ile bütünüyle çelişiyordu. İşte bu çelişki, mülkiyetten yoksun olanların dışlanmasıyla bir toplumsal gerilim yaratıyordu. Bu da burjuva ile normlarının ve hiyerarşik ve asimetrik bir ilişkinin "sözde" meşruiyetine meydan okuyacak bir temeli ve nedeni oluşturuyordu.

Bu çelişki ve nedenler "edebi kamusal alan" olarak tanımlanan birahaneler, kafeler, okuma kulüpleri ve salonlarda paralel bir şekilde gündeme geliyordu. Burjuva kamusal alan, ailenin özel alanında ortaya çıkmış olması yanında, sonuçta siyasal bir nitelik kazanmıştı (Melton, 2011: 16-19). "Sokak bir buluşma mekanıdır ve o olmadan belirlenmiş yerlerde (kafe, tiyatro, salon) buluşmak imkansızdır" (Lefebvre, 2013: 22).

Kapitalizmin gelişmesinin ve sanayileşmenin ilk dönemlerinde var olan yoksul kitlelerin, burjuva kamusal alanına katılımın ön şartı olarak kabul edilen mülkiyet olanağına sahip olamaması evrensel iddiaların sınırlarını apaçık ortaya koyuyorlardı. Çünkü mülkiyete sahip olanlar ve olmayanlar arasında bir anlamda doğal bir ayırım ortaya çıkıyordu. Hem toplumsal açıdan refah devleti anlayışı hem de görünüşte "özel” olan ama gerçekte giderek yarı-kamusal bir nitelik kazanan kurumların artan gücü bu ayırımın bir anlamda temelini zayıflatıyordu. Çünkü devlet ile toplum arasındaki sınırlar erozyona uğruyor, ailenin mahremiyeti ise giderek devletin ve yar1-kamusal kurumların müdahalesine konu oluyordu. Böylece aile artık özerklik kalıntılarını kaybederek, dış güçlerin müdahalesine maruz kalıyor ve sonuçta edilgen (pasif) bir "ev-içi alan" düzeyine düşüyordu. Öte yandan kamusal alan da eleştirel nitelik ve sivriliğini kaybederek iletişim, reklamcılık ve kitle tüketim kültürünün egemenliği altına giriyordu.

Kamusal alan, özel olan ile kamusal olanı birbirine bağlıyordu. Şöyle ki, kafe, tiyatro ve salonlarda gelişen sosyalleşme pratikleri, soyluları burjuvalardan ayıran sınırları kaldırma eğiliminde olsa da, aslında soylularla burjuvaların bütünleşme sürecine katkıda bulundukları ve yeni bir elit haline getirdiği söylenebilir. Burada kamusal alan, burjuva sınıfının oluşum süreci olarak tanımlanabilir, çünkü kamusal alan kapitalist toplumsal ilişkilerle özdeşleştirilebilir. Bu bakımdan, her ne kadar "kapitalizm kamusal alanın tabut taşıyıcısı olsa da aynı zamanda, ebesiydi (Melton, 2011: 24)". Çünkü kapitalist piyasa ilişkileri, ticari bir niteliğe dönüştürülmüş boş zaman ve tüketim biçimleriyle kamusal alanı içeriyordu. Görülen ve izlenen şey, genişleyen iletişim ağları ve buna erişim olanağı olanlarla-olmayanlar arasında gittikçe büyüyen bir uçurumun oluşmasıdır. İlişkilerin ve sürecin tümüne bakıldığında görülen, kamusal olan ile özel olan arasındaki sınırların istikrarsız, belirsiz ve hep değişkenlik göstermesidir.

Oysa, I. Illich'in ideal toplum olarak ele aldığ 1 ve "modern teknolojilerin, yöneticilerden çok siyasal açıdan birbiriyle ilişkili bireylere hizmet ettiği (İllrich, 2011: 11) "şenlikli toplum"lar, tüm üyelerinin, başkalarınca asgari ölçüde denetlenen araçlar yoluyla özerk eylemde bulunmalarına imkan verecek şekilde tasarlanmalıdır (Illich, 2011: 33). Çünkü bireyler, eylem içinde ve aktif şekilde hükmettiği veya pasifçe boyun eğdiği araçları kullanarak, yaşadığı toplumla ilişki kurmaktadır. Ona göre, fiziksel veya toplumsal tüm araçlar herkes tarafından kolayca istenen sıklıkta ve kullanmanın seçtiği amaçlar için 
kullanılabildiği zaman "şenlikli toplum” oluşturulabilir (Illich, 2011: 33-34). Bu da kamusal olan ile özel olan arasındaki dengenin sağlanmasında yardımcı olacaktır.

\section{KAMUSAL ALAN VE DEMOKRASI}

Anlaşıldığı üzere, kamusal alan herkese açık bir görünme ve görüşme mekanıdır, bu sayede hem insanları bir araya getiren hem de birçok alt "kamusal alan"lara ayıran bir alandır. Bu yapıdaki bir kamu alanı, dünyaya bakış haline dönüşmüştür. Bu bakış bağlamında, kişisel ve toplumsal hakların diğer haklar üzerinde egemenlik kurmadan gerçekleştirilmesi yollarının bulunması beklenmektedir. Çünkü özne halinde özel birey kesimlerinin yanında, özne haline gelemeyen toplumun zayıf kesimlerinin korunması süreci üzerinde düşünülmesi yolları geliştirilmesi gereksinimi vardır (Tekeli, 1999: 8-10).

1980’li yılların neoliberal hareketi küreselleşmeyi önceleyen bir süreç niteliğindedir. $\mathrm{Bu}$ süreç toplumda daha gevşek örgütlerin, yatay ilişki ağının güçlenmesinin vb. oluşumların kökenini oluşturur. Buna karşın, kamusal ve özel alanların ayrışması olgusu karşısında klasik liberal demokrasiler doyurucu bir cevap vermekte yetersiz kalmaktadır. Çünkü sınıfsal yapıların çözülüyor ve eski keskinliklerini yitiriyor gibi görünmesine karşın, emek-sermaye çatışmasının giderek farklı özellikler göstermesi, siyasal partilere ve siyasal sürece duyulan güveni azaltmıştır. Çünkü amaçlaştırılmış bir demokrasi anlayışı ona olan bağlamı zayıflatmış ve onun kamusal denetimden uzaklaşmasına yol açmıştır. Oysa, "denetim...demokrasinin kamusal alandaki paydaşıdır” (Kahraman, Keyman ve Sarıbay, 1999: 17).

Kamusal alan ve demokrasi bağlamında kamu (public) kavramı "herkese açı"” anlamını içerir ve buradan da anlaşılacağı üzere kamu, özel olandan ayrı bir alan olarak kendini ortaya koyar. Kamu bazen de kamu gücünün karşıtı bir kamuoyu alanı olarak da sunulur. Bu durumda, bazen devlet organları bazen basın kamusal alanın organları sayılırlar.

Kamusal-özel alanların ayrımı giderek kamusal (ortak) çıkara dayalı yurttaş-bireyler toplumu ile, kendi özel-bireylerin çıkarlarına dayalı burjuva toplumu arasındaki temel ayrıma dönüşmüştür, ki bu politik alan ile ekonomik alan ayırımı olarak daha önce varolan bir ayırımın izdüşümü ve uzantısıdır. Zamanla sivil toplum ile devlet arasındaki ayırım doğmuş ve bu ayırım burjuva kamusal alanının temeli olarak belirmiştir. Kamusal alan "gerçekten devlete karşı bir konumdaymış gibi göründü. Diğer yandan, toplumun giderek ilgi alanına girmesiyle beraber, pazar ekonomisi gelişmesinin başındaki üretim olgusu da özel alandaki yerel otoritenin sınırlarının dışında gelişmeye başladı, burjuva kamusal alanı, bireylerin kamusal organ içinde örgütlendiği özel bireylerin alanı haline geldi (Habermas, 1997: 64)”.

H. Arendt'e göre, kamusal alanın bir özelliği onun ortaya çıktığı ortam ise, diğer özelliği bireyleri ve toplumu bir arada tutan dünya ve bu dünyanın "herkese açık" oluşudur. Ancak bu sayededir ki, deneyimler paylaşılır ve kimlikler açıklanabilir. Bu da bizi hem birleştirdiğini hem de gerekirse birleştirmediğini gösterir. Böylece kamusal alan, topografik (kara parçasına ilişkin) ve kurumsal olmayan nitelikte özgürlüğün kendini gösterebildiği yerdir. Buna göre, çeşitli topografik yerler eğer ortak eylem ve iktidar alanları haline geliyorsa bunlar kamu alanı sayılabilir: Kent meydanı veya parkı buna örnek verilebilir. "Gerçekte sokak, ...fonksiyonları da içermektedir: bilgilendirici, sembolik... sokaklarda, insanlar karşılaşmazlar, birbirlerine yaklaşırlar" (Lefebvre, 2013: 22-23). Öyleyse kamusal alan kavramının ikili bir anlamı vardır: Hem içinde çalışmaya ya da emeğe karşıt olarak eylem gibi 
belirli bir etkinliğin gerçekleştirildiği yerdir, hem de karşılıklı diyalogun tözel (asıl, cevher) içeriğiyle ilişkili olarak diğer toplumsal alanlardan farklılaşmadır (Arendt, 1994).

Buradan da anlaşılmaktadır ki, kamusal alan, sadece özel alan karşıtlı̆̆ ikilemi içermez ve "özel-kamusal - (farklı) kamusallıklar" ayırımı yapılabilir. Burada "özel” olan bireysel öz çıkarları; "kamusal" olan toplumun ortak kararlarını; "kamusallıklar" ise etnik ve dinsel vb. çıkar, kimlik ve inanç gruplarını kapsar. Dikkat edilirse görülecek nokta şudur: Farklı kamusallıklar, bir anlamda kollektif (toplumsal) bir anlamda ise özel nitelikler gösterirler, yani kollektiftir çünkü ortak normlar tarafından yönlendirilirler, özeldir çünkü bireylerin özgül ihtiyaçlarının ifade edilmesini sağlayabilirler (Kahraman, Keyman ve Sarıbay, 1999: 38).

\section{KAMUSAL ALAN VE MAHREMIYET (GIZLILIK)}

Feodal sistemin giderek ortadan kalkmasıyla birlikte kamusallığın bir anlamda taşıyıcısı olan kilise, prens, soyluların iktidarları, bir yandan özel ögelere diğer yandan kamusal ögelere ayrıldı. Doğaldır ki, özel olanlar devlet aygıtı alanının dışında kalma anlamına gelmiş, buna karşılık kamusal olanlar devleti ima eder hale gelmiştir. Habermas bu gelişimi şöyle açıklar: "Kamusal, özel olan her şeyin aksine kamu kurumuydu. Devlet memurları, kamusal şahıslar bazı resmi görevlerle yükümlüydüler, bunların resmi görevi kamusaldı ve hükümet binalarına ve kurumlarına kamu deniyordu. Öte yandan, bağımsız bireyler, özel hizmetler, özel görevler ve özel evler vardı...kamu görevinin dişında kalanlar kendi özel çıkarlarının peşinde koşarken, yetkili makamların kamu yararına hizmet ettiği söyleniyordu" (Habermas, 2012: 71).

Кати, giderek bir kamusalı birlikte oluşturmak şeklinde özel şahısların toplamı anlamına gelmeye başlamış ve "efkar-1 umumiye" (kamuoyu) terimini de birlikte taşımıştır. Bu iki kamu kavramı, hem resmi hem de bağımsız bireylerin toplamı olmak üzere birlikte açıklık kavramını oluşturdu. Kamusal alan akla dayalı bir alan olacaktı. Bu da "insan aklının kamusal kullanımı” olacaktı (Neocleous, 2014: 107 ve Dacheux, 2012: 15-16).

Hem resmi hem de bağımsız bireylerin toplamı olmak üzere birlikte ortaya çıkan açıklık ilkesinin net ve tek hedefi, gizlilik'e karşı olmaktı. Burada elele giden iki süreç bir aradadır: Bir yanda mahremiyete (gizliliğe) yönelik artan bir vurgu, öte yanda ise devlet gizliliğini sınırlandırma talebi. Bireyin mahremiyete çekilmesi devletin gizliliklerinin kaybı ve saflaşması anlamına geliyordu. Öyle ki, özel olan tümüyle özel olurken, kamusal olan giderek daha kamusal oldu. Özel alanın bu tutumu ve kamusal alanda açıklığın arttırılması talebi, burjuva sınıfının ve ideolojisinin merkezî stratejik ögesi oldu (Neocleous, 2014: 110).

Oysa, gizlilik devlet erkinin dahi bir parçasıdır ve devlet erkini meşrulaştırır. Öte yandan, özel olan mülkiyet ile birleştirildiğinde sadece bireysel bir şahısla değil de tüzel kişilerin talep ettiği dışlayıcı mülkiyet haklarıyla ele alındığında dışlanmış kesimler ve emek açısından farklı sonuçlar yaratacağı açıktır. Mülkiyet ve mahremiyetin bireysel insan haklarını savunmasına ilaveten, yeri geldiğinde kolaylıkla tüzel kişilerin ve sermayenin haklarını savunmasında kullanılabileceğini yeniden düşünmek gerekir.

Kamusal alan ile birlikte oluşmuş/oluşturulmuş "kamuoyu" kavramı örneğin 18. yüzyılda öncelikle Fransa'da ve daha sonrada İngiltere'de giderek olgunlaşmıştır. Kamuoyu kavramı Fransa'da 18. yüzyıl gazetecilik yazınında da ortaya çıkmıştır ve bu kavramın enazından teoride kurumsal bir ayağı olmuş/oluşturulmuştur. İleride göreceğimiz üzere 
1870'lerde Fransa'da Maliye Bakanlığı yapan J. Necker'in hazine hesaplarını yayınlamış olması bu konuda ilk ve en önemli adımlardan biridir (Melton, 2011: 73). Fransa halkının Hollanda, Almanya ve Brüksel'deki yabancı basın organları dışında başka siyasal bilgilenme kaynaklarının olması kamuoyunun oluşması sürecinde önemlidir.

$\mathrm{Bu}$ oluşumda rol oynayan diğer kaynaklardan birisi, Fransız sarayının büyüklüğü, dönemin mutlak monarşisinin gizliliğine engel oluyordu. Çünkü sarayda yaşayan ve istihdam edilen 20 bin kadar insanın bulunması, bir o kadar çift göz ve kulağın olması demekti ve sarayın kapalı kutu olmasını engellemiştir. Saray içi hizipler, saraya ilişkin bilgiler ve saraydaki dedikodular bilgi ve haber akışı için önemli araçlar idi. Ayrıca, dönem içinde girişilen savaşlar siyasal bilgi akışını hızlandırmıştı. Öte yandan, döneme ve yönetime ilişkin komplo iddiaları ise özellikle kıtlık dönemlerinde ister istemez yayılıyordu. Çünkü 18. yüzyılın hemen her büyük kıtlık krizinde çok sayıda Fransız, tahıl sıkıntısı ve kıtlığın, sadece kötü iklim koşullarından değil, daha çok, halkı aç bırakacak sinsi ve gizli bir komplodan kaynaklandığı inancını taşıyordu. Bu komplolarda çoğunlukla kralın bir bakanının parmağı olduğu kanaati doğuyordu. Hatta komplonun bir diğer uzantısı olarak, Fransız hükümetinin tahıl ticaretini ele geçirerek hazineye daha çok gelir sağlamak için fiyatları artırdığı dahi söyleniyordu. Dahası, maliye bakanı Ossy'nin tekel konumundaki tahıl tüccarları ile beraber tahıl pazarına müdahale ettiği suçlamaları yapılıyordu. Doğaldır ki bu dedikoduların siyasal kültürde bir inandırıcılık payı söz konusuydu (Melton, 2011: 85-87). Bir yorumcuya göre, Fransa' daki "devrimde kumpas fikri ... eylemi örgütlemek ve yorumlamak için bir referans noktası olmuştur” (Melton, 2011: 90). İngiltere'de ise halkın bu yöndeki şüpheciliği ve dedikodu alanı saraydan çok, yerel ve bölgesel yönetimleri kapsıyordu (Melton, 2011: 87).

Dolaysıyla, kamuoyunun adeta bir mahkeme olarak, gücü ellerinde tutan kurum ve kişilerin eylemlerini yargılayan bağımsız bir organ gibi ele alınması, bu kavramı siyasal bir kilit ögesi haline getirmiştir.

Birahane, kafe, okuma klüpleri, salonlar, tiyatroların kamuoyu oluşması ve mahremiyetin yorumlanması bağlamında yorumuna ilişkin şu ifadeler çok dikkat çekicidir: Aydınlanma çağı filozoflarından F. M. Grimm, tiyatro seyircisi hakkında, "bizim partnerimizden daha adil, daha kesin ve daha dakik" olduğunu belirtir; Alexander Pope, tiyatro seyircisine "çukurun çok başlı canavarı" sıfatını takar. Gazeteci J. Pezzl, Viyana birahanelerini "siyasal dedikodu tapınakları" olarak adlandırır; Leipzigli eleştirmen Th. J. Quistrop, "kafeler siyasetin borsasıdır...en saklı hakikatleri gün 1şığına çıkarırlar", der (Melton, 2011: 184-185, 262 ve 274). Benzer bir yorumu F. Nadir, "meyhane halkın parlamentosudur" adlı gazete makalesinde yapar (Nadir, 2014). Öyleyse iletişim mekanları olan meyhane, birahane, kafe, tiyatro vb. gibi yerler Lefebvre' ye göre; birer "iletişim mekanı olan sokaktan geçiş, hem zorunludur hem de baskı altında tutulur." Öte yandan, yine "sokak, tüketim için/tüketim tarafından organize edilen bir şebekeye dönüşmüştür...tüketimin neokapitalist tarzda örgütlenmesi, gücünü sokakta gösterir” (Lefebvre, 2013: 24).

\section{DEVLET İKTIDARI VE SIVIL TOPLUM}

Sivil toplum ve burjuva toplumu anlamına gelen deyimleri kullanarak Hegel, sivil toplum alanının iki özelliğini vurgulamıştır: Önce, sivil toplum, devlet iktidarının ve siyasal olanın karşısındaki sosyoekonomik olandır, sonra bu yeni alan özünde burjuva niteliğindedir. Yani bu alan atomize niteliktedir ve bencil bireylerin egemen olduğu alandır. Bununla birlikte, sivil toplumun ortaya çıkışının burjuva niteliği yanında, kendisinin özünde modern 
bir yönü vardır. Yani siyasal devletin çağdaş bir ürünüdür ve modern toplumun yabancılaşmış ilişkilerinin bir yönüdür. Çünkü bu alan aynı zamanda kendisini yok etme tehdidi taşıyan yoksulluk ve zenginlikleri bir arada üretir. Bu nedenledir ki, Hegel kamu hizmetlerini modern devletin bu olumsuzluklarını gidermenin bir özelliği olarak görmektedir.

Marx ise, sivil toplum analizine karşı, devleti ve sivil toplumu yeniden bir araya getiren görüşün özellikle toplumsal gereksinimler alanında bir maddi dayanağı olduğunu belirtir. Zira yabancılaşmanın ve yoksullukların ortadan kaldırılacağı temel baz buradadır. Çünkü devlet içerisinde elde edilen veya verilen özgürlükler yeterli olmamaktadır. Sadece siyasal özgürlük, toplumsal insani özgürlük demek değildir. Açıktır ki, toplumsal özgürlük ihtiyaçlara (gereksinimlere) ve emek alanına gönderme yapıyor iken, siyasal özgürlük ise sadece biçimsel özgürlüğe atıfta bulunur (Neocleous, 2013: 34). Aksi halde, "burjuva toplumunun siyasal olarak sağlamlaştırılması, toplumsal mücadelenin devlet tarafından örgütlenmiş bir yönetsel biçim altında aşılarak korunmasını içerir (Neocleous, 2013: 35)”.

Bu noktada Marx üç ana boyuta işaret eder::Birincisi, "aracı" rol oynayan kurumlardan çoğunun devletin kurumları olduğunu; ikincisi, sivil toplumun ardındaki gerçek itici gücün "gerçek" mücadelenin yaşandığı arenanın bulunduğunu; üçüncüsü, devlet ve sivil toplum ayırımının nasıl giderileceğini belirtir. Sonuçta ise, ona göre bu üç boyut denge içinde bir arada bulunmalı ve tarihsel materyalizm bu üç boyutu da içermelidir (Neocleous, 2013: 36).

\section{BURJUVA KAMUSALLIĞININ OLUŞUMU VE DÖNÜŞÜMÜ}

Habermas'a göre halk, kulistir; öyle ki soyluların, kilise mensuplarının ve en belirgin öge olarak kralların oluşturduğu Ortaçağ egemen zümreleri bu kulisin önünde kendilerini meşru göstermeye çalışır ve statülerini temsil ederler. Halk, bu temsilî kamunun temel ögesi ve koşullarından biri niteliğindedir. Halk kültürü de, egemen ögelerin kurduğu hiyerarşik dünyaya ve ilişkilere karşıt bir oluşum ve isyan özelliklerini taşır. Burjuva toplumunda özel alanın çekirdeğini ve kendi kendisine dönük bir öznelliğin çıkış noktasını oluşturan çekirdek ailenin ataerkil (patrimonyal) bir karakter taşıdığı açıktır (Landes, 1988).

Burjuva kamusunun yapısal özellikleri devlet-kamu, ekonomi-sivil toplum-bireydışlanmışlar bağlamında ele alınırsa, bunun kamusal alana olan olumlu ve olumsuz uzantıları daha belirgin şekilde ortaya çıkar. Ortaya çıkan sonuç, bizi kamusallığın yapısal bir dönüşüm geçirdiği anlayışına kolaylıkla yaklaştıracaktır.

Kamunun yapısal dönüşümü üç ana boyutta gerçekleşmiştir: Önce; konumuz itibariyle esas olan ve gözden uzak tutulmaması gereken nokta, kamunun yapısal dönüşümünün, devlet ve ekonomideki dönüşümün ve deviniminin içinde ortaya çıktığıdır. Çünkü kamu erki ile özel hukuk ve alana göre örgütlenmiş olan iktisadi toplum arasındaki ilişki, hem liberal temel haklar teorisine hem de özünde demokratik olmayan bir hukuk devleti oluşumuna dayanır.

Kişilerin özgür iradeleriyle oluşmuş toplum üyelerinin öz-örgütlenmesi, devlet ile toplum arasında ayrışma yaratmıştır. Bu ayrışmaya ilaveten bir de, piyasalar üzerinden yönlendirilen ekonominin, ortaçağdaki veya modern-öncesi siyasal egemenlik düzenlerinden ayrışması vardır. Bu da, kapitalist üretim biçiminin giderek kendini kabul ettirmesiyle birlikte ortaya çıkmıştır. Bu gelişme veya ayrışmaların birleştiği veya kendiliğinden bir arada oluşturduğu ortak nokta, burjuva toplumunun ve onun örgütlenmiş iktisat toplumunun ekonomik özyönetimi ve özerkliğidir. Burada, devletle ekonominin birbiriyle iç içe olması, 
burjuva özel hukukunun oluşturduğu liberal temel haklar anlayışı, toplumsal modelin dayandığı temeli giderek sarsar ve çürütür.

Sonra, burjuva toplumu (sivil toplum), özel bir alan olarak kamu gücünün, yani somut ifadesiyle hükümetin karşısına konulmuştur. Hem mal mübadelesi ile toplumsal emeğin alanı hem de üretken işlevlerden uzak olan aile alanı, burjuva toplumunun özel alanına dahil edilmiştir. Yani, özel mülkiyete sahip olanların üretim sürecindeki konumu özel alanın özerkliğinin temelini oluşturmuştur. Oysa ekonomik yönden bağımlı olan özellikle emek sınıfı için bu yolun yapısal bağ pek oluşmamıştır. Ancak, düşük gelirli bu sınıfın toplumsal örgütlenmesi ile sınıf çelişkilerinin siyasallaşmasıyla, ailenin özel mahremiyet (gizlilik) alanının birbirine zıt şekilde yapılaşmış olduğu hususu toplumsal bilince çıkmıştır. Bu durumda özel yaşam alanı sadece diğerlerinden ayrışmakla kalmamış, kentleşme ve bürokratikleşme yanında, işletmelerin temerküzü (merkezileşmesi) ve kitle tüketiminin oluşması gibi değişimlere de uğramıştır. Oysa, kitlelerin dayandığı toplumsal zemin sadece özel mülkiyet olamazdı, zira kitlelerin katılım haklarını talep etmeleri gerekirdi. Çünkü ekonomik açıdan bağımlı olan ve mülkiyete sahip olmayan kitlelerin özel mal ve sermaye mübadelelerine katılım yoluyla egemen olamayacakları belliydi. Bu nedenle de, bu kitleler sosyal devletin güvencelerine muhtaç durumdaydılar. Özel mülkiyet sahipliğine dayalı özerklik ve eşdeğerlilik ancak refah devletinin bu vatandaşlara vereceği statü güvenceleri ile kısmen sağlanabilirdi. Sosyal devletin reel yaşamda gerçekleşmesi ise, devletin üretim araçları ve dolaysıyla iktisadi iktidar üzerindeki özel tasarruf gücüne müdahaleleriyle mümkün olacakt1.

Nihayet, temelde devletle toplumun entegrasyonu ile kamunun yapısal dönüşümü sağlanabilecektir (Habermas, 2012: 25-30).

Yine de, söz konusu oluşum ve dönüşümler sonucu; ekonomi ve devlet aygıtını, kapitalist ve burjuva sistemince birleştirilmiş alanlar olarak görmek mümkündür. Çünkü varılmak istenen hedef, kapitalist düzlemde ve doğrultuda özerk hale gelen iktisadi sistemin ve bürokratik egemenlik sistemlerinin elbette tümüyle ortadan kaldırılması değil, fakat sistemin yaşam alanlarındaki buyurgan müdahale ve tecavüzlerine son verilmesidir. Ancak, böylece toplumsal entegrasyon (bütünleştirme) gücü, ekonomik ve bürokratik iktidarlara karş1 kendini kabul ettirebilme ve yaşamın yarattığ gereksinim ve taleplerine gerçeklik kazandırabilme olanakları doğacaktır.

\section{MUHALİF (ELEŞTİREL) KAMUSAL ALANIN DOĞUŞU VE SAYDAMLIK}

Kamunun, bir mahkeme gibi, yönetim erkini ve gücünü elinde bulunduran kişi ve kurumların eylem ve tasarruflarını yargılaması kamusal alan kavramının kilit bir ögesidir.

Kamusallık gücünü yansıtma amacını taşıyan bu tür önemli örneklerden biri, 17701780'lerde Fransa' da maliye bakanlığı yapan J. Necker'in bir siyasal güç olarak kamuoyunun önemine gösterdiği duyarlılıktır. Onun, 16. Louis döneminde hükümet icraatlarını gözleyen bir otorite olarak kamuoyuna bilgi vermesi önemli bir olgudur.

Şöyle ki; J. Necker savaşın finansmanı için kredilere başvurmuştu, fakat dönem hükümetinin kredi alabilmesi için potansiyel kreditörlerin monarşinin mali yapısına güven duymaları gerekiyordu. Necker, güvenilirliğin temelinin kamuoyunda saklı olduğunu söylüyordu. Öte yandan, kamu kredisinin, despotizm karşısında bir engel olduğu da vurgulanıyordu. Necker, tahtın bütçesini yayımlama yönünde bir adım atmış ve 1781 yılına 
ait Compete rendu'yu (rapor-hazine hesabını) açıklamıştır. Necker, tahtın gelir ve giderlerini yayınlamış olmasını, tahtın mali işlemlerine olan güveni tazeleyecek ve hatta arttıracak bir önlem olarak savunmuştur. Necker'in bu tasarrufu hükümettekileri dehşete düşürmüş ve bir diğer bakan ise bunun kraliyetin gizliliğinin kutsal geleneklerini ihlal ettiğini belirtmiştir. Necker ise, kurumsal bir denge olabilecek kanaat organları yaratmayı amaçlıyordu. Bu amaçla da, taşrada özyönetim kurumları kurma planı çerçevesinde yerel meclisleri, monarşinin saydam ve açık olmayan mali sistemine açıklık getirmenin bir aracı olarak görüyordu. Bunun için bu meclisler, tahtın koyduğu doğrudan vergileri (taille gibi) belirleyip toplayacaktı. Ayrıca, yoksul insanlara yardım yapılması ile diğer kamu faaliyetleri için sorumluluk taşıyacaktı. Necker, vergi koyma ve toplama yöntemlerini kamuya açık hale getirerek, krallığın mali yönetiminin güvenilirliğini aksatan keyfilik ve yolsuzlukların bu meclisler tarafından giderilebileceğine inanıyordu. Temel amaç ise, yerel meclisler aracilığıyla kamunun güveninin sağlamaktı. Gerçekten de, yerel meclisler siyasal inisiyatifin, taht (krallık)tan ve parlamentodan genel olarak topluma ve ulusa geçmesi sürecini hızlandırmıştır. Meclisin gelir ve giderlere ilişkin görüşleri basılı bütçeler olarak geçerliliğe ve sürüme kavuşturulunca, konuya ilişkin tartışmalar giderek ulusal bir olay haline gelmiştir (Melton, 2011: 73-75).

\section{KAMUSAL TOPLUM VE KAMUSAL AKIL}

Kamu, burjuva toplumunda kendini kamusal topluluk olarak bir araya gelmiş olan özel bireyler olarak ortaya koyar. Özel bireyler, kamuoyunu, kamu gücüne karşı sahiplenerek, bu güçle mal dolaşımı ve toplumsal emekle ilgili kurallar konusunda hesaplaşmaya girişirler. $\mathrm{Bu}$ siyasal mücadelenin kendine özgü bir aracı ise "kamusal akıl yürütmedir" (Rawls, 1996). Dilbilimsel açıdan bu sözcük hem akla atıf (gönderme) yapar hem de bu çabayı bir anlamda küçümser.

Önceleri değişik topluluklar, kral (hükümdar)larla, toplulukların özgürlüğü ile kralın otoritesi arasında denge sağlayacak bir sınır çeken anlaşmalar yapmışlardır. Bu uygulama 1215 Magna Carta Libertatum'dan da öğrenileceği üzere, önce topluluk ile prensler arasında ikilik ortaya çıkmasına yol açmış, bir süre sonra, hükümdarın karşısında toprağı yalnızca, kırsal gruplar temsil eder hale gelmiştir. İlk ve yeni burjuvalar özel kişilerdir ve bu özel kişiler kamusal erke yönelik iktisadi ve iktidara ilişkin taleplerini, bölünmesini istedikleri egemen kişiye veya erke doğrudan yöneltmezler, ama alttan alta ve dolaylı olarak bu egemenliğin dayandığı temel öge ve ilkeleri hedef alırlar. Çünkü bireyler, Kant'a göre "tek başınayken azınlık olmaktan kurtulamaz...Buna karşılık, kamunun kendi kendini aydınlatması daha gerçekçi bir olasılıktır.” İnsanların kendi değersizliklerinden kurtulmasına olanak sağlayan aklın bu kamusal kullanımı halkın mantığı üzerinde etkilidir (Dacheux, 2012: 15-16).

Kamusal toplumdaki makul düşünceden gelen hoşgörü argümanı tüm geniş halklar topluluğu için de geçerlidir. Yani, eğer toplumlar arasındaki ilişkide kamusal akıl uygulanıyorsa, hoşgörünün (toleransın) ortaya çıkması kaçınılmazdır. Burada halkların temel çıkarları; güvenliklerini, topraklarını ve vatandaşların refahını garanti altına almak, yasal bağımsızlıklarını korumak ve özgür kültürlerini yaşatmaktır (Rawls, 2006: 19. 36).

Her toplumda vatandaşlar (veya halklar) kamusal akıl kavramını temel alırken öte yandan yöneticilerin bu kavram bağlamında harekette ve tasarrufta bulunmalarını ister ve zorlarlar. Vatandaşların kendilerini bir anlamda yapıcı ve uygulayıcı gibi görmeleri, onların 
kamusal akla aykırı hareket eden yöneticileri reddetmeleri halklar arasında karşılıklılık ve barış anlayışının bir parçasıdır.

Burada, muhalifler yetersiz ya da anlayışsız diye bertaraf edilemezler, çünkü “ortak iyi" ve adalet anlayışı ancak karşılıklılık ve muhaliflerin gayretleri ile sağlanabilir (Rawls, 2006: 59-60, 65). Zıt görüşte olanlar arasındaki uzlaşma da, adil karar verilmesi ve kamusal akıl yürütülmesi halinde olumsuzlukların yok olacağı fikrine dayanır. J.Rawls, kamusal aklın üç yönden kamusal olduğunu vurgular: Özgür ve eşit vatandaşların aklı olarak kamunun aklıdır; konusu kamu yararıdır ve kamusal akıl yürütme ile ifade edilmektedir (Rawls, 2006: 145).

Kamusal akıl düşüncesindeki en önemli öge, "vatandaşların...kamusal aklı çiğneyen hükümet yetkililerini...reddetmekte...yaygın bir tutum göstermeleridir (Rawls, 2006: 148).

Özel kişilerin kendi mahremiyet (gizlilik) tercihlerine karşın, mevcut egemenliğin karşısında savundukları temel ilke olan aleniyet (açıklık), bu egemenliği değiştirmeyi amaçlar. Kendisini kamusal akıl yürütme sürecinde ortaya koyan fakat egemenliğe talip bir tarzda olmayan bu iktidar talebi, artık egemenliğin sadece meşruiyet temelinin değiştirilmesiyle yetinmeyecektir. Özel bireylerin bir araya gelmesi esas kamunun oluşumunu öncelemiştir, ama kamusal bir topluluk çerçevesindeki kamusal akıl, açıklıktan uzak durmak zorundadır. Çünkü aklın kamusallığı gizliliğine bağlıdır ve kendini korumak için "maskelenmiş" aklın ışığının adım adım açığa çıkacağı düşünülmüştür. Zaten 18. yüzyıl boyunca oluşan cemiyet türü birleşimler giderek açı birlikler haline gelmiş ve bu birliklerde burjuva davranış tarzı kendisini kabul ettirmiştir. Hepsi de, özel bireyler arasında süreklilik kazanan bir tartışmayı örgütlemişler ve bunun sonucunda rütbe-mevki törenselliğinin yerini giderek eşdeğerlik ölçüsü almıştır (Habermas, 2012: 94-95, 104-105).

Habermas'ın kamusal alan için öngördüğü üç varsayım; tartışmalarda tek hakemin aklın gerekleri olduğu, hiçbir şeyin eleştiriden muaf olmadığı ve açıklığın temel bir ilke olduğudur. Buna göre; "kamuoyu"nun kolektif yargıların hükümeti daha akılcı hale getirebilmesi, ama kamuoyunun akılcı olması için de bilgilendirilmesi ve hükümetin işlerinin saydam olması önşart idi. Buradan hareketle, bu varsayımlar ve yaklaşımlar 18. yüzyıl liberalizminin ve sivil toplum anlayışının temel özellikleri olacaktı.

\section{KAMUSALLIK DİYALEKTİĞI}

Rawls'ın "kamusal akıl”, Kant'ın "kamusal mutabakat (uzlaşma)” ve Hegel'in "kamu oyu" olarak adlandırdığı şey, aslında, akıl yürüten özel bireylerin oluşturduğu kamusallıkta vücut bulur, bu anlamda ete-kemiğe bürünür.

Rawls'ın kamusal aklı kullanan liberal bakış dizgesi karşılıklılık, açıklık ve uzlaşmayı esas alarak burjuva toplumunun sorunlarını çözüm yollarını irdelerken, Hegel aynı burjuva toplumundaki entelektüel ve ahlaki oluşum eşitsizliğini ve bu yolla bu toplumdaki derin çatlağı görmüştür. Çünkü bu toplumlarda, ihtiyaçlar nedeniyle hem servet birikimi artıyor hem de özel emek soyutlanarak sınırlanıyordu. Bu da emeğe bağlı olan sınıfın bağımlılığının giderek artması ve sefaletin büyümesi olarak ortaya çıkıyordu. Hegel'in "tüketim azlığı" teorisi, siyasal akıl üreten özel mülk sahiplerinin ortak çıkarını, salt bir kısmî çıkar olması nedeniyle, genel kabul görmekten uzaklaştırmış ve bir anlamda itibardan düşürmüş ve çıkar çatışmalarının bulunduğunu göstermiştir. Çünkü kamusal topluluk olarak bir araya gelen özel bireylerin oluşturduğu kamuoyu, artık birliğin sağlanması için bir temel olmaktan çıkar, 
sadece çok sayıda özel bireyin kanısı olmak durumuna düşer. Hegel'in ifadesiyle sadece "mülkiyeti ve şahsi özgürlüğü güvence altına alıp korumayı gaye edinen" bir devlet, özel şahıslardan oluşan ve "organik olmayan bir kanaate ve talebe yol açar ve organik devlete karşı salt yığınsal bir güç “ haline gelir. Sanayi ve ticaret özgürlüğüne ilişkin çıkarlar, bencil amaçlara saplandığı ölçüde, böylesine bir bağımlılığa giderek daha fazla gereksinim duyulur. Kamusallık kavramı eğer böylesine daraltılmış bir özel alanda ortaya çıkmışsa, bu kavram artık liberal ve temel alınan bir öge olarak kabul edilemezdi. Oysa kamuoyu, sağduyulu biçimde ortaya çıkıyor ve önyargılar şeklinde toplumun içine yayılıyor ve gerçekliğin ihtiyaçlarını yansıtıyordu (Habermas, 2012: s.218-222)

Marx ise kamuoyunu, "yanlış bilinç" olarak nitelendiriyor ve onun burjuva sınıf çıkarları olduğunu belirtiyor. Ona göre, kapitalist sistem kendi haline bırakılırsa, ücretli işçilikten mülk sahipliğine yükselme olanakları giderek azalır ve sınıflı bir toplum oluşur. Sermaye birikimi sürecinde, piyasalarda tekelleşme görülür ve serbest fiyat mekanizması ortadan kalkar; bu da, yeni iktidar ilişkilerine zemin oluşturur. Öyleyse kamusal topluluğun ulusla, toplumun da ulusla özdeş olduğu söylenemez. Çünkü mülkiyete sahip olanlarla ücretli işçiler sınıfı arasındaki karşıtlık nedeniyle, mülk sahiplerinin mal dolaşımı ve emek alanının bir özel alan olarak kalmasına yönelik çıkarları sadece kısmî bir çıkar seviyesine iner; mülk sahiplerinin özel alanlarına yönelik çıkarlar da, emek sahipleri üzerinde güç kullanılarak yaşama geçirilir. Devlet ile toplumun ayrılmasına paralel olarak, kamusal insan ve özel insan arasında bir bölünme ortaya çıkar. Burjuva olmayan tabaka veya sınıflar siyasal kamuya girdikçe, o zaman burjuvazinin kamusallık silahı kendi aleyhine döner. Çünkü, mülk sahibi olmayan kitle, toplumun temel kurallarını bizaat kendi kamusal muhakemesi veya kamusal aklı haline dönüştürdüğünde, toplumsal yaşamın yeniden üretilmesi genel bir siyasal iktidar sorunu haline dönüşür (Habermas, 2012: s. 230-231). Tekrar hatırlanmalıdır ki, gerçek anlamda bir siyasal iktidar, bir sınıfın diğerlerini baskı altında tutmak amacıyla örgütlenmeyi amaçlar.

\section{KAMUSALLIĞIN OLUŞUMU VE İKTISSADİ MALİ SÜREÇLER}

Floris'in deyimiyle, “ticari ekonomi alanı ile kamusal alan arasındaki... ilişkilerin tarihine kayıt düşmeden, kamusal alan ile dayanışma ekonomisi arasındaki ilişkiye göz atılamaz. Zira... kapitalist ve demokratik toplumları karakterize eden şey, politik yaşamı, kurumlararası ilişkileri...yapılandıran kamusal bir alanın varlığıdır. Bu bizi pazar ekonomisinin işleyişi ile siyasal demokrasi arasındaki ilişki sorusunu sormaya götürecektir (Floris, 2012: s.65-66)"

Kapitalizmin ilk dönemlerinde muhafazakar (tutucu) olduğu söylenebilir, bunda kazanç elde etme saik ve modelinin dayandığı ticaret pratiğinin siyasal olarak da muhafazakar nitelikte olması göz önünde tutulmalıdır. Eski üretim tarzları olan; özgür olmayan köylülük üretim süreci, tarımsal üretim, şehirlerde zanaatkarlık ve küçük meta üretiminin somut sonuçları ile beslendiği sürece, kapitalizmin seyri kararsız ve çelişik kalır. Çünkü, kapitalizm hem var olan egemenlik ilişkilerinin aynen kalmasını ister ve onu sağlamlaştırır, hem de bu ilişkilerin çözülmesine yol açacak ögelerin önünü açar, ki bu da yeni tedavül (dolaşım) ilişkilerinin bir uzantısıdır. Bundan kastedilen, erken kapitalist dönemde varolan iç ve yakın mesafeli ticaretin yanı sıra özellikle uzun mesafeli ve dış ticaretin yapılması ve malların ve bağlantılı haberlerin dolaşımıdır. 
Gerçi erken kapitalist dönemde kentler, kuruldukları ilk dönemlerden beri yerel pazarlara sahip idiler, fakat uzun mesafeli ticaret ilişkilerinin kurulmasıyla birlikte, kentler artık birer mal ve hizmet ticaretinin "hareket üssü" konumuna gelmiş ve bunun sonucunda yeni pazarlar oluşmuştur. Hatta bu pazarlar mali sermaye teknikleri ve hareketleri sonucu kısa sürede borsalar olarak kurumlaşmışlardır.

Tahmin edileceği üzere, büyük ticaret kentleri, aynı zamanda bir haber dolaşım merkezi niteliğine kavuştular. Zaten borsaların oluşmasıyla, posta hizmetlerinin ve basın ve iletişimin kurumlaşması hemen hemen aynı zamana rastlar (Habermas, 2012: s.75)

Kamu yönetiminde mali açıdan kamusallık siyasetinin ilk önemli ve belirgin örneği 1215 Magna Charta Libertatum (Büyük Ferman)'dur. Bundan sonraki genel gelişim çizgisi izlenirse; geç ortaçağın feodal toplumu olarak özel alandan ayrışmış, kendi başına bir alan olarak kamudan bahsedilemez. Bununla beraber, yerel prenslerin hükümranlık ögesi olarak prens mühürlerinin veya damgalarının "kamusal" olarak tanımlanması bir tesadüf değildir; çünkü, egemenlik bu ögelerle kamusal bir nitelikte temsil edilir. Bu temsili kamu, kendini bir kamu alanı olarak ortaya koymaktan çok, bir statï belirtisidir. Zira, toprak beyinin veya prensin statüsü, kamu ve özel ölçütler açısından tarafsızdır.

18. yüzyılın sonuna dek ayakta kalan feodal erkler, kilise ve feodal beyler ayrışarak bir kutuplaşma sürecine girmiş ve sonuçta bir yanda özel diğer yanda kamusal ögeler olacak şekilde parçalanmıştır. Prenslik erkinin kutuplaşmasına etki yapan ilk gelişme, kamu hazinesinin toprak beyinin özel mülkünden ayrılmasıdır. Böylece prenslik mülkiyetinin devlet (kamu) mülkiyetinden ayrılması, kişisel egemenlik ilişkilerinin nesnelleşmesi bakımından önemli bir örnektir. Çünkü devlet hazinesi, egemenin kişiliğinden bağımsızlaşmış ve ortak devlet bütçesine dönüşmüştür. Doğaldır ki, bunda tebaaya (veya halka ve daha sonra vatandaşa), devlete karşı kamu mal ve hizmeti taleplerinde bulunabilme olanakları sağlamıştır (Habermas, 2012: 71, 79).

Goldscheid, kamu maliyesinin sosyolojik analizine ayırdığı ünlü makalesinde bunu açık ve anlaşılabilir şekilde anlatır: Önce her şey; toprak, insan ve tüm varlıklar mutlak egemenin malvarlığı içinde kabul edilirken, sonraki yüzyıllarda bu varlıklar özellikle egemen ve kısmen temsilci olduğu düşünülen meşrutî meclis veya kurullar arasında bölüşüme uğramış, en sonra demokratik yönetimlerde yöneticinin kendine ait varlıkları ile toplumun ve halkın varlıkları tamamen ayrılmış ve cumhurbaşkanı, başbakan ve bakanlar gibi yöneticiler bir anlamda maaşlı görevli haline dönüşmüştür (Goldscheid, 1967).

Bu genel gelişim ve bölünümün uzantısına paralel olarak erken kapitalist dönemde, mal ve haber dolaşımı güçleri, ilk kez ulusal ve bölgesel ekonominin modern devletle paralel olarak geliştiği merkantilist iktisat aşamasında kendilerini gösterme araç ve olanaklarına sahip olmuşlardır.

16. yüzyıldan başlayarak genişleyen ve büyüyen bir sermaye birikimi ile giderek daralan pazarlarla yetinmeyen ticaret şirketleri kurulmuştur. Bu şirketler, bir yandan kendi pazarları için yeni ticaret bölgeleri keşfetmiş, yerel pazarları sömürmeye gitmiş, öte yandan kendilerine anonim şirket yapısını oluşturmuşlardır. Bu da devletlerin geniş bölgeleri kapsamaları sonucunu yaratmıştır. Şehir ekonomilerinin ulusallaşması da bu yolla başlamış ve "ulus" diye tanımlanan şey, bürokratik kurumlarıyla ve artan mali gereksinmeleri nedeniyle 
merkantilist politikayı hızlandırmıştır. Bu yolla da modern devletin oluşması ve kuruluşu sağlanmıştır (Habermas, 2012: 78-79).

Mal ve haber dolaşımının borsalar ve basın aracılığıyla sağlanması ve sürekliliği ister istemez kesintisiz ve örgütlü bir devlet etkinliğini gerekli kılmış ve kamu erki erişilebilir bir varlık olarak pekişmiştir. "Kamusal" kavramı buradaki dar anlamıyla devlete ilişkin olanla eşanlama gelmiş, kamu erkinin dışında kalan özel şahıslar, kamu erkinin muhatapları olarak halkları oluşturmuştur.

Merkantalist iktisadi ilişkiler ve politika, yönetenler ile yönetilenler arasındaki ilişkilere kendine özgü bir çehre kazandırmıştır. Bunun yanında, ayrıcalıklı şirketlerin tekel konumunda bulunduğu dış ticaret pazarlarının açılması ile yeni sömürgecilik doğmuş ve bu şirketler giderek sanayi sermayesinin hizmetine girmiştir. Mal dolaşımı ve üretim yapısı kaçınılmaz ve köklü dönüşüme uğramıştır. Artık dış ticaret, yerli halkın işgücünü harekete geçirdiği ölçüde zenginliğin temel kaynağı olmuştur. O zaman, yönetimin aldığı tüm önlemler kapitalist üretim tarzının yerleşmesini hedeflemiştir. Tahmin edileceği üzere, özelleşmiş iktisadi faaliyetler, artık kamusal gözetim altında yönlendirilmiştir. Bu yolla iktisadi koşullar da ilk kez genel (kamusal) çıkarın temel konusu haline gelmiştir (Habermas, 2012: 80-81). Bu durumda, toplum insanların hemcinslerine olan bağımlılıklarının oluştuğu ve kamusal alanın fizyonomisini de belirleyebildiği bir birlikte yaşama biçimidir (Arendt, 1994: 43).

Merkantilist mantıklı modern ekonomi anlayışında antik çağdaki "ev"in yerini "pazar" almış ve ekonomi "ticaret bilimi"ne dönmüştür. Feodal beyin hazine odası anlamına gelen "camera"dan doğan ve 18. yüzyıl merkantilizminin uzantısı olan "kameralizm"inde siyasal ekonominin (politik iktisat) ticaret bilimi, maliye biliminin geleneksel ekonomiden ayrilan öğretisinin yanı sıra konumlandırılmıştır. Bu yolla da burjuva toplumunun özel alanı kamu erkinin organlarıyla bir araya gelmiştir.

Aynı dönemde basın, kapitalist mal dolaşımı ağına yardımcı bir öge olarak gelişmiş ve haberleşme, meclislere savaşlara, ürünün verimine, vergilere, değerli madenlere ve elbette uluslararası ticari dolaşıma ilişkin ayrıntılı bilgiler ulaştırmıştır. Bu haberleşme sadece mal dolaşımına bağlı olarak önem kazanmamış, buna ilaveten kendisi de alınıp satılan bir mal haline dönüşmüştür. Ne var ki, basını çok geçmeden yönetimin isterleri yönünde kullanmaya başlayan yönetimlerin çıkarları ağır basıyordu ve basın giderek bu yönetimlerin çıkarlarına hizmet eden bir öge ve alan haline gelmiştir (Habermas, 2012: 82-84).

$\mathrm{Bu}$ dönemde, ticaret ve sanayi sermayesinin gelişmesine karşın, zanaatkar ve esnaf gibi bir anlamda "ilk burjuva" grubu toplumsal ve ekonomik olarak önem kaybetmiş olup, büyük tacirler, şirketleri aracılığıyla devletle doğrudan bağlantılar kurmuşlardır. Hemen her kentte tacir, bankacı, borsacı, yayıncı ve manifaktürcüler de "yeni burjuva" grubu içinde yer edinmişlerdir.

Kamusal topluluğun burjuva kamuoyu olarak, özel alana yönelik kamusal çıkarları sadece hükümetçe fark edilmekle kalmayıp, artık tebaa tarafından da göz önüne alınması ölçüsünde gelişmeye başlamıştır. Ticari ve mali sermaye sahiplerinin yanında yayıncılar, manifaktür atölye üreticileri ve fabrikatörler de giderek yönetimin önlemlerine bağımlı hale gelmiştir. Bu grupların iktisadi faaliyetlerinin kayıt altına alınması yanında, iktisadi olarak daha inisiyatifli olmaya zorlanmaları gözetilmiştir. Bunun arkasında, merkantilist işletme politikasına eşlik edecek kapitalist özel işletmelerin kurulması teşvik edilmiştir. İşte bu 
noktada, hükümetle tebaanın ilişkisinde, kamusal düzenleme ve özel girişim arasındaki çelişkinin etkileri ortaya çıkmıştır.

İster istemez, kamu erkinin özel şahıslarla bağlantısının doğduğu her alan bir dizi sorunsalı ortaya çıkarır. Çünkü geçimlik kesimin ve emek faktörünün alanı daralmış, yerel pazarların bölgesel ve ulusal pazarlara bağımlılığı artmıştır. Toplumun geniş kesimi merkantilist politikaların etkilerini günlük yaşamlarında görmüşlerdir. Kamu finansmanına yönelik vergi, harç ve ev bütçeleri ve kamusal müdahaleler bağlamında kritik bir uygulama alanı ortaya çıkmıştır. Örneğin, tahıl kıtlığı döneminde, yapısal bir düzenlemeyle ekmek tüketimi yasaklanmıştır. O zaman devletin bu tasarrufuna karşı çıkan toplum, hem kamu erkinden özel olanı koparmış hem de kamusal akıl yürüterek kamusal eleştiriyi oluşturmuştur (Habermas, 2012: 86-87).

\section{KAMUSAL ALAN VE EKONOMI İLİŞKISİ}

19. yüzyılın burjuva kamusal alanına bakılırsa, işletme ve özellikle pazar dinamiklerinin kamusal alandan bağışık olduğu görülür. Bu dönemde ekonomik alan, ekonomik ve politik süreçlerin liberal kapitalizmle birlikte ekonomik alanın hemen hemen tümüyle özel olana intikal etmesi veya aktarılması sonucu devlet egemenliğinden kurtulmuştur. Devlet, liberal mantığın, "bırakınız yapsınlar, bırakınız geçsinler" ilkesinin geçerli olduğu bu dönemde, pazarın temel işleyişiyle henüz tam birleşmemiştir. İşletme ve pazarın aktörlerinin yaşamı, mal ve mülkiyet sahiplerinin tek egemen güç kaynağıdır. Mal ve mülkiyet sahipleri bu özgürlükleri geniş ölçüde kullanmış ve bu çerçevede; çocukların çalıştırılması, sınırsız çalışma saatleri, çok düşük ücretler, işçilerin keyfi olarak işten çıkartılması, sendika yasağı ve benzer diğer baskılar yaygın bir uygulama alanı bulmuştur.

Özel ekonomiler ile kamusal alan arasındaki bu uyuşmazlık, kapitalizm ile demokrasi arasında savunulamaz ve yapısal bir karşıtlık bulunduğunu açıkça göstermiştir. Zaten 1929 krizinden sonra, ekonomi alanı, kendi özel yapısından sıyrılmış ve Keynesci mantık uzantısında sosyal devlet ve mantıkla iç içe duruma girmiştir. Ne var ki, politik olan ile ekonomik olanın birbirinin içine girdiği (veya nüfuz ettiği) bu dönem, bir yandan ekonomik alanı kamusal alana doğru yaklaştırırken, öte yandan kitlesel medya ve reklamcılık iletişimi ile ticari dağıtım ağları da gelişmiştir (Floris, 2012: 67-68).

Günümüzde şirketlerin ve kollektif birimlerin kamusal alanı kapladığı bir dönem yaşanıyor. Bu da ekonomik alanın İkinci Dünya Savaşı sonrasından 1970'lerin sonuna kadar kitlesel tüketim aracılığ 1 ve araçları ile kamusal alana yaptığ “yatırım”ın bir sonucudur. Buna göre, medyadaki reklam iletişimi ve ticaret merkezleri biçiminde yeni kamusal yerler ortak yaşam alanları üretmiş durumdadır. Pazarın ve şirketlerin kamusal alanı kaplaması (daha şiddetli bir deyimle istilası), özel şirketlerin kamusal görünürlüğünün pek olmadığı bir dönemin sonunda gerçekleştirilmiştir.

1970'lerden sonra kamusal alanın yapısı, 1960'lardaki güç ilişkilerinin dönüşümü sonucu alt-üst olmuş ve pazarlama biçim ve teknikleri, kamusal alanda iletişimin vazgeçilmez unsurları olarak toplumsal gerçekliğin kavranılışına damgasını vurmuştur. Çünkü "kökeninde reklamcılık olan pazar tarafından kamusal alanın sürekli bir ele geçirilmesi süreci söz konusudur (Floris, 2012: 69)". Kamu hizmetlerinin sunumunda kamu sektörü, özel sektör ve kar amacı gütmeyen sektör örgütlerinin ortaklığına ilişkin yeni bir örgütlenme modeli olarak önerilen kamu yararlı şirketler, devlet merkezli sosyal demokrasinin ve piyasa merkezli 
yeniçağın ötesinde çok daha geniş tabanlı olduğu iddia edilen "üçüncü yol” arayışının bir uzantisidır (Karasu, 2009: 117).

\section{KAMUSALLIĞIN TOPLUMSAL VE SIYYASAL YAPISININ DÖNÜŞÜMÜ}

Kamusal alanın özel alan ile ilişkisine bakılırsa; burjuva kamusunun, devletle toplum arasındaki mevcut gerilim sahasında fakat özel alanın parçası olarak kalacak şekilde geliştiği görülür. Burada temel bölünme ve gerilim, toplumsal yeniden üretim ile siyasal erklerin ayrışması anlamına gelir. Zira kapitalist iktisadi pazar ilişkilerinin genişlemesi ve derinleşmesi ile birlikte, sınıfsal egemenliklerin kısıtlayıcı çerçevelerini değiştiren ve hatta parçalayan "toplumsal" olanın alanı belirginleşir. Toplumsal alanın giderek belirginleşmesi sonucu, devletin payına yeni fiziksel ve sosyal mal ve hizmet fonksiyonlarını yerine getirme görevi düştükçe, onunla toplum arasındaki ayırıcı duvar çökmeye başlar. İktisadi ve sosyal gücün mal dolaşımının özel alanda yoğunlaşması sonucu, ekonomik yönden güçsüz olan ve mülkiyete sahip olmayanlarda doğal bir eğilim gelişir, ki bu da pazardaki konumu açısından üstün durumda olana "siyasal karşı durma" eğilimidir.

Devletin bu yeni işlev ve görevlerinin giderek artmasını ve müdahale eğilimini K.Galbraith; ABD için devlet bütçelerinin artan etkisi ve boyutlarının genişlemesi ile açıklar (Galbraith, 1952). Bu yönde, S.Fabricant ve R. Lipsey de 50 yıllık kamu harcamaları trendini sayısal verilerle destekler (Fabricant ve Lipsey, 1952). Aynı gelişimin dayandığı mantığı Wagner, kamu harcamalarının artış teorisi ile zaten daha önce analiz etmiştir. Özel alana yönelik bazı kamusal müdahaleler devletin daha önce yerine getirdiği işlevleri daha genişlemesine yapması, ayrıca yeni bir dizi işlevi yüklenmesi zorunlu hale gelmiştir.

Devlet bazen özel bireyleri kamusal görevlerle yükümlendirerek bazen de özel iktisadi işlevlerin eşgüdümünü yüklenerek veya doğrudan üretici üretici ve dağıtıcı işlevler yürüterek birçok hizmetlere girişmiştir.

Devlet bazı kamu hukuku alanlarını terkederek bazı görevlerini ise özel girişimcilere ve kurumlara aktararak, bir yandan özel hukuk alanının kamulaştırılmasına, öte yandan da kamu hukuku alanının özelleştirilmesine yönelmiştir. O zaman sermayenin yoğunlaşması ve müdahalecilikle birlikte "devletin toplumsallaşması" ve "toplumun devleştirilmesi”" süreçleri ile karşı karşıyayız demektir. Böylece kamu yararının kamusal ögesi, özel hukukun ögesi ile kaynaşım göstermiştir. Öyleyse, oluşan bu yeni alan ne saf özel ne de gerçek anlamda kamusal olarak adlandırılabilir (Habermas, 2012: 251-265). Şimdi karşımızda, özel veya kamusal olarak anlamlandırılamayacak bir yeni yapı, daha doğrusu "toplumsal alan" (public sphere) kavramı çıkar. $\mathrm{Bu}$ yeni alanda toplumun devletleştirilmiş ve devletin toplumsallaştırılmış alanları birbirlerinin içine girmiştir.

Öte yandan, kamusal topluluğun sırtından bazı görevler, bir yandan dernekler ve sivil toplum kuruluşları öte yandan siyasal iktidar adayı partiler tarafından alınır ve iktidar kullanımı ve güçlerin dengelenmesi süreci bunlar arasında gerçekleşir.

Genel eğilim olarak burjuva kamusu alanın ve mantığının değişmesi, dönüşmesi ve hatta giderek yıkılışını hazırlayan önemli bir süreç, kamusal alanın özel alan ile kaynaşması, burjuva kamu modeli olan özel alanın kamusal alandan kesinlikle ayrılması öngörüsünün çökmesi anlamına gelir. 
Öta yandan, Marx tarafından mülksüz kitlelerin, ekonomik mücadeleyi siyasal mücadeleye çevirmek için kamunun kapılarını zorladıkları saptanmıştır. Bunun uzantısı olarak, siyasal kamunun mülksüzlerce sahiplenilmesi devlet ile toplumun kaynaşmasına yol açmıştır. Kamusal alanın özel alanla kaynaşmasının paralelinde devlet ile toplumun karşılıklı olarak birbirlerinin içine girmesi sonucunda görece homojen olan kamusal topluluğun dayandığı temel de sarsılmıştır.

Örgütlü özel çıkarların rekabeti de kamuya nüfuz etmiş ve orada tekil çıkarların rekabeti sergilenmeye başlamıştır (Habermas, 2012: 298-303).

\section{SONUÇ}

Kamusallığın siyasal işlevine bakılırsa, aleniyet (açıklık, saydamlık) işlevinin dönüşüm geçirdiği görülür. Bunu yaratan temel gelişim, kamusallığın topografik ve yerel zeminini kaybetmesi ve özel alan ile "dünya kamusu/kamu oyu" ile belirgin olan sinırının ortadan kalkması ve saydamlığını yitirmesidir. Öyle ki, siyasal partilerin özel alandan kamu alanına sarkan dernekler, sivil toplum kuruluşları ve cemiyetlerin çıkarlarına aracılık yapmak zorunda kalmaları ve parçalanmaları gündeme gelmiştir. Bunun yansıması olarak parlamentolar da, kamusal tartışma mekanları ve organları olmaktan çok, birer gösteri heyeti olmaya evrilmişlerdir. Yani parlamentolar; siyasal erk ve organların, yani iktidardaki partilerin radyo, televizyon ve gazeteler aracılığıla politikalarını halka sundukları ve savundukları, muhalefetin ise bu politikalara karşı çıkarak alternatif politikalarını geliştirdikleri "kamusal kürsü”ler haline geldiler. Reel uygulamada, asıl danışma ve tartışmaların parlamentoların genel kurulundan ziyade meclis komisyonlarına ve gruplarına kayması, parlamentonun kamusal danışma (istişare) işlevinin gerisine çekilmesi demektir. Tartışmalar sadece birer şov (gösteri) haline bürünüyor ve böylece açıklık ve saydamlıkla yapılması gereken kritik (olumlu-olumsuz eleştiri) niteliğini kaybediyor (Habermas, 2012: 335-339).

Özünde bireysel ve özel şahısların oluşturduğu ve ilke olarak alındığı özellikler dışında çalışan (veya artık işlemeyen) kamusal toplulukların yerini artık örgütlü özel şahısların çıkarlarını güden bir kamusal topluluk almaktadır. "Bugünkü koşullarda... kamusallığın kanalları üzerinden ve örgütlerin devletle ve birbirleriyle alışverişi için yürürlüğe kon(ul)muş bir aleniyet temelinde kamusal bir iletişim sürecine etkili katılım sağlayabilecek yegane (özne) budur" (Habermas, 2012: 377). O zaman denilebilir ki, parlamentolar, özünde sosyal güce karşı yönelmiş olan fakat kendisi bir güç olarak kurulmuş bulunan bir kurum olmanın çelişkisiyle sakatlanmıştır. Buna karşılık olarak da, sosyal devlet anlayışı ve koşulları çerçevesinde işleyen kamusallık, bizzat kendisini, kendi kendini yaratacak bir güç niteliğine kavuşturmak; kendi kendini oluşturmak görevi ve pozisyonu taşımalıdır (Habermas, 2012: 374). 


\section{KAYNAKÇA}

AKŞİT, Elif Ekin, 2009, "Osmanlı İmparatorluğu ve Türkiye'de Kamusallık Kavramının Dönüşümü ve Dışladıkları”, Ankara Üniversitesi Siyasal Bilgiler Fakültesi Dergisi, 64(1), 1-21.

ARENDT, Hannah, 1994, İnsanlık Durumu, (Çev. Bahadır Sina Şener), İstanbul: İletişim Yayınları.

BECKER, Marvin, 1994, The Emergence of Civil Society in the Eighteenth Century, Bloomington: Indiana University Press; First Edition edition.

DACHEUX, Éric, 2012, “Kamusal Alan: Demokrasinin Anahtar Bir Kavramı”, Kamusal Alan, (Der. E. DACHEUX), Çev. Hüseyin Köse, İstanbul: Ayrıntı Yayınları.

FABRICANT, Salomon and LIPSEY, Robert E., 1952, The Trends of Government Activities in the USA Since 1900, NBER Books, New York,

FLORIS, Bernard, 2012, "Kamusal Alan ve Ekonomik Alan”, Kamusal Alan (Der. E. Dacheux), Çev. Hüseyin Köse, İstanbul: Ayrıntı Yayınları.

GALBRAITH, Kenneth, 1952, American Capitalism, Boston: Houghton Mifflin.

GOLDSCHEID, Rudolf, 1967, "A Sociological Approach to Problems of Public Finance", Classics in The Theory of Public Finance, (Eds: R. Muscrave and A. Peacock), New York, Macmillan

HABERMAS, Jürgen, 1997, Kamusallı̆̆ın Yapısal Dönüşümü, (Çev. Mithat Sancar ve Tanıl Bora), İstanbul: İletişim Yayınları

HABERMAS, Jürgen, 2012, Kamusallı̆̆ın Yapısal Dönüşümü, (Çev. Mithat Sancar ve Tanıl Bora), İstanbul: İletişim Yayınları.

ILLICH, Ivan, 2011, Şenlikli Toplum, (Çev. Ahmet Kot), İstanbul: Ayrıntı Yayınları.

KAHRAMAN, Hasan Bülent, KEYMAN, E. Fuat ve SARIBAY, Ali Yaşar, 1999, Katılımcı Demokrasi, Kamusal Alan ve Yerel Yönetim, İstanbul: WALD.

KARASU, Koray, 2009, "Yeni "Kamusal” Örgütler: Kamu Yararı Şirketleri”, Ankara Üniversitesi Siyasal Bilgiler Fakültesi Dergisi, 64(3), 117-147.

LANDES, Joan B., 1988, Women and the Public Sphere in the Age of the French Revolution, Ithaca and London, Cornell University Press.

LEFEBVRE, Henri, 2013, Kentsel Devrim, (Çev. Selim Sezer), İstanbul: Sel Yayıncılık.

MELTON, James Von Horn, 2011, Aydınlanma Avrupasında Kamunun Yükselişi, (Çev. F. B. Aydar), İstanbul: Boğaziçi Üniversitesi Yayınevi

NADİR, Feridun, 2014, "Meyhane Halkın Parlamentosudur", Birgün Gazetesi, 22 Haziran 2014.

NEOCLEOUS, Marc, 2013, Sivil Toplumu Yönetmek-Devlet İktidarı Kuramına Doğru, (Çev. Bahadır Ahıska), Nota Bene Yayınları / Politika Dizisi 
NEOCLEOUS, Marc, 2014, Devleti Tahayyül Etmek, (Çev. Akın Sarı), Nota Bene Yayınları / Politika Dizisi

RAWLS, John, 1996, Political Liberalism, New York: Columbia University Press.

RAWLS, John, 2006, Halkların Yasası ve Kamusal Akıl Düşüncesinin Yeniden Ele Alınması, (Çev. Gül Evrin), İstanbul: İstanbul Bilgi Üniversitesi Yayınları.

TASSIN, Étienne, 2012, "Ortak Alan mı Kamusal Alan mı? Topluluk ve Aleniyetin Karşıtlı̆̆ı”, Kamusal Alan (Der. E. Dacheux), Çev. Hüseyin Köse, İstanbul: Ayrıntı Yayınları.

TEKELİ, İlhan, 1999, “Önsöz”, Katılımcı Demokrasi, Kamusal Alan ve Yerel Yönetim, (Editörler: Ali Yaşar Sarıbay, Hasan Bülent Kahraman, E. Fuat Keyman), İstanbul: Demokrasi Kitaplı̆̆ 
